\title{
Does It Pay to Be "Greener" than Legislation? An Empirical Study of Spanish Tile Industry
}

\author{
Conrado Carrascosa-López ${ }^{1}$, María-del-Val Segarra-Oña ${ }^{1,2}$, Ángel Peiró-Signes ${ }^{1} \&$ \\ Baldomero Segura-García-del-Río ${ }^{3}$ \\ ${ }^{1}$ Management Department, Universitat Politècnica de València, Valencia, Spain \\ ${ }^{2}$ INERTE, International Network for Economic Research on Tourism and Environment, Spain \\ ${ }^{3}$ Social Sciences Department, Universitat Politècnica de València, Valencia, Spain \\ Correspondence: Conrado Carrascosa-López, 7D building, Management Department, Universitat Politècnica de \\ València, Camino Vera s/n 46022 Valencia, Spain. E-mail: concarlo@upvnet.upv.es
}

Received: February 11, 2012 Accepted: April 6, 2012 Online Published: May 1, 2012

doi:10.5539/jsd.v5n5p17

URL: http://dx.doi.org/10.5539/jsd.v5n5p17

\begin{abstract}
Environmental awareness is a key aspect considered in companies' corporate social responsibility. Companies try always to comply with current environmental legislation. Does it make sense for them to go beyond legislation? This work's aim is to answer this question and to study how companies can generate value through environmental proactivity. This study is focused on the Spanish tile industry sector. This research's objective is to describe which aspects form companies' environmental strategy; barriers and facilitators that make possible proactive environmental orientation; benefits companies can obtain from it and obstacles companies face when trying to be environmentally proactive, through a case study as qualitative methodology. The major benefit observed is to prevent sanctions, followed by improvement of corporate image, long-term cost savings and new business opportunities obtaining. Main obstacles companies face are lack of institutional and financial support. Evidence is found that environmental proactivity is considered in companies' strategic planning.
\end{abstract}

Keywords: environmental proactivity, sustainable development, tile industry

\section{Introduction}

The interest in protecting the environment is increasing over the years and in all areas, both in society and in the business scope, in service and industrial sectors (Vargas-Vargas et al., 2010). Global demand is appreciating more and more the products obtained with low environmental impact and energy efficiency (Porter \& Van der Linde, 1995). Industrial sector has repeatedly been responsible for harming the environment. The threat of global warming worries a lot nowadays (Altomonte, 2008). These dangers have been reduced over the years due to the growing environmental awareness and the creation of laws and regulations to control pollution caused by industries (Fairchild, 2008).

Environmental proactivity is a part of the proactive behavior in organizations. This proactive behavior in organizations is complex; it's caused by multiple phenomena, and can have important consequences for both personal and organizational development (Crant, 2000). It is interesting to know what are the reasons, motives, causes and determinants for this voluntary environmental disclosure. Environmental proactivity construct has tried to be measured by different authors, it is necessary to know their contribution to knowledge for a better understanding. It is interesting to recognize the benefits gained with its application and the correlation between them and environmental performance.

The main objective of this research is to study environmental proactivity impact in the tile industry sector. This main objective breaks down in three objectives. The first one is to identify environmental proactivity facilitators; internal characteristics of companies that help develop proactive environmental performance, exploring company size, internationalization trend and direct involvement of management. The second objective is to identify the obstacles faced by companies for their environmental proactive approach. The third objective is to identify what benefits can be expected after the proactive environmental behavior.

The structure of this paper is as follows. First a literature review in environmental proactivity is written, considering its motivating factors, its measurement and the benefits of its application. Second a brief overview of 
the tile industry sector in Spain. Then qualitative methodology used in this research is presented. The paper continues with the results exposure, discussion and conclusions.

\section{Literature Review in Environmental Proactivity}

The term proactivity can be defined as the trend to initiate changes on the own free will, rather than waiting and reacting to events. Strategic proactivity is the skill of firms to initiate changes rather than react to events (Aragón-Correa, 1998). Corporate proactivity can be understood as taking initiative in improving current circumstances or creating new ones involving the challenge of the status quo (Crant, 2000). The proactivity referred to the environmental conservation is the environmental proactivity concept, voluntary implementation of practices aimed at improving company’s environmental impact (González-Benito \& González-Benito, 2006).

Environmental proactivity determining factors can be divided into internal or external to the company. The internal are; management implication, big size and belonging to an international company. The external are; industrial sector and location, as social pressure and environmental legislation depend on them (González-Benito \& González-Benito, 2006). Besides, González-Benito and González-Benito (2010) consider essential stakeholders' commitment for the development of proactive environmental strategies. Aragón-Correa et al. (2008) studies SMEs and proves that big size is not a necessary condition to have a proactive environmental strategy. Gadenne et al. (2009) explains that in despite of finding companies with "green discourse" management, however the level of environmental practices was not as green as the discourse.

Ability to generate proactive strategic approach is dynamic and business environment is important for its generation. This generation of proactive environmental strategy can be facilitated or obstructed by the company and its environment (Aragón-Correa \& Sharma, 2003). Proactive motivation can be influenced with awareness of potential benefits which may follow environmental practices (Gadenne et al., 2009). Therefore, proactive environmental performance of the same company can vary over time, companies with significant environmental performance improvements; have improved previously their financial capacity and/or management skills. And similarly, those with worse environmental proactivity performance have previously suffered difficulties with financial resources and/or management skills (Clarkson et al., 2011).

There are studies that analyze different patterns of environmental response to the pressure influence from stakeholders (Murillo-Luna et al., 2008). For instance customers role, because it is observed different responses in companies with different positions in the supply chain, specifically between B2B companies (Business to business) or $\mathrm{C} 2 \mathrm{C}$ (Close to consumer), concluding that pressure and therefore performance is better among $\mathrm{C} 2 \mathrm{C}$ companies than among B2B ones (Haddock-Fraser \& Tourelle, 2010).

In order to measure environmental proactivity, it is required to measure the implementation of several environmental practices. It is necessary in the same way the empirical approach to be able to recognize comparative effects of those factors affecting environmental performance to identify what influences each of them (González-Benito \& González-Benito, 2006; Aragón-Correa \& Sharma, 2003). Australian Environmental Attitude Scale is one measurement form that compiles responses of series of likert scale questions on environmental observed attitudes, used by (Gadenne et al., 2009) in their research.

There is some research linking environmental proactivity with obtaining benefits. Aragón-Correa (1998) defines environmental proactivity impact as positive as a new advantage positioning. According to King and Lenox (2001) sometimes proactive behavior is good for both environment and companies. Current research is more specific, describing more in detail the obtained benefits, for instance, as corporate image improvement (Buysse \& Verbeke, 2003). González-Benito (2005) reveals that some aspects of environmental proactivity lead to positive effects on the performance of the company itself as well as in marketing activities. Gadenne et al. (2009) lists more benefits; waste reduction, cost savings, increasing customer satisfaction, product improvements and companies public relations. Recent studies in this field add that environmental proactivity is and aid for internationalization processes (Martín-Tapia et al., 2010) and even to improve financial resources (Clarkson et al., 2011). Continuing with the benefits, some research can be found linking adoption of environmental management systems with value creation for the company. Rondinelli and Vastag (2000) verify in a case study that ISO 14001 adoption leads to company changes that transform the company positively. Melnyk et al. (2003) demonstrate that USA industrial sector obtain real benefits from ISO 14001 certification. Darnall et al. (2008) find empirical evidence in a research performed with industrial companies from Canada, Germany, Hungary and United States, that business value has been created after implementation of environmental management systems. In Spain Segarra et al. (2011a) reveal the same profitable relationship in the food industry.

The most common way of approaching to environmental proactivity in the existing literature is through quantitative studies based on surveys or interviews (Aragón-Correa, 1998; King \& Lenox, 2001; Melnyk et al., 
2003; Buysse \& Verbeke, 2003; González- Benito \& González-Benito, 2005; Dias-Sardinya \& Reijnders, 2005; Sharfman, 2008; Aragón-Correa et al., 2008; Darnall et al., 2008; Murillo-Luna et al., 2008; Piñeiro-García et al., 2009; Darnall et al., 2010; Martín-Tapia et al., 2010; Haddock-Fraser \& Tourelle, 2010; Delmas et al., 2011; Clarkson et al., 2011; Segarra, 2011a, Lopez-Gamero et al., 2011). Statistical studies confirm the relationship between different factors, but do not explain the origin and the causes of these relationships (González-Benito \& González-Benito, 2010). Case studies in this field are much rarer, but some case studies have been found (Rondinelli \& Vastag, 2000; Gadenne et al., 2009).

Environmental proactivity can be facilitated and some obstacles can stand in the way of its progress (Aragón-Correa \& Sharma, 2003). Little research has been found regarding difficulties faced by companies that would desire to improve their environmental performance. Lack of financial resources is one of the most important barriers that hinder environmental practices (Gadenne et al., 2009).

It is important to go deeper into the company to be able to understand which are the abilities supporting sustainable strategies. Delmas et al. (2011) consider absorptive capacity as the fundamental one. "Green attitudes" don't correspond always with "green facts", that is the reason why Gadenne et al. (2009) recommend empirical studies. This is one of the reasons why case study has been chosen for this research, because case studies are necessary to understand the true impact of environmental proactivity, they are the right tool to look inside companies to let explain the reasons, causes and consequences of its application.

\section{Spanish Tile Industry Sector Brief Overview}

Spain is the second European producer of ceramic tiles and the third world exporter, behind China and Italy. The Spanish tile industry sector produced in year 2010,366 million of ceramic tiles $\mathrm{m}^{2},(37 \%$ of EU-27). It employs 16200 persons directly and more than 5000 indirectly. It exports to 182 countries for a total value of 1673 million Euros. Being the total sales of the sector of 2547 million Euros (Ascer, 2010).

The Spanish tile industry is highly geographical concentrated in Castellón's province (Tortajada et al., 2008; Albors-Garrigós et al., 2008), since $94.5 \%$ of the Spanish national output is concentrated in the area delimited in the northern part by Borriol and Alcora, in the western part for Onda, in the southern part for Nules and in the eastern part for Castellon de la Plana. Its importance in the Valencian Community is very big, since it has been for many years the first investing sector and the second exporter (only behind car manufacturers).

\section{Methodology}

An explanatory case study methodology has been developed according to Kaplan (1986), to figure out how facilitators and obstacles of environmental proactivity influence competitiveness. Fourteen cases were studied according to Rouse and Daellenbach (1999).

The method to be used in this study, in-depth interviews, is considered as direct data collection (Stake, 1995). The followed interview type is called structured open-ended interview (King, 1994). This technique combines closed questionnaires advantages with qualitative research interviews. Following Dubé and Paré (2003) some of their proposals have been taken into account to have high rigor level when using case studies as the methodological research. We have followed their three areas structure when designing our study. Firstly, design related aspects, as identifying clear research questions, taking advantage of pilot cases in order to help refine the design and the data, collection plans, to conduct more longitudinal case studies and, exploiting the richness of several data collection methods. Secondly, questions regarding data collection methods; procedure aspects as number of interviews, and interviewees, use of an interview guide, instrument validation etc; effectively use of tables to summarize information about the data collection process. And last, data analysis procedures in order to provide clear descriptions; use of preliminary data analysis techniques and tools and compare findings with existent literature (both similar and conflicting) in exploratory case research so as to increase the confidence in the findings.

Following Flyvbjerg (2006), to achieve the greatest possible amount of information on a given problem or phenomenon, atypical or extreme cases reveal more information, for that reason the cluster company leader, Porcelanosa, has been studied together with another tile manufacturer competitors and auxiliary companies, all of them belong to the tile industry cluster in Castellón as well.

A Likert scale questionnaire was prepared with five possible answers and a sixth alternative answer when there is not enough information. The questionnaire was filled personally by the researchers in order to classify the company in terms of its environmental proactivity, at the same time qualitative additional information was gathered trough informal talks with employees and observation of company's products and manufacturing 
processes. In this way a system was established to measure environmental proactivity integration into company's business strategy (Stake, 1995).

The questionnaire is composed of 42 questions focused on identifying aspects that make possible the company to be characterized in terms of its environmental proactivity.

Before its final circulation, the questionnaire was tested to verify and discuss the appropriateness of the questions, with personal interviews with companies' directors or managers, in order to obtain more reliable results. Proximity to reality, which the case study entails, and the learning process that it generates for the researcher will often constitute a prerequisite for advanced understanding (Flyvberg, 2006).

The intention is to study particularly which is the influence of environmental proactivity in the tile industry sector and particularly in Castellón's cluster companies. The cluster is known as a model where the nearness of the companies and the support institutions promote important increases of competitiveness (Miret-Pastor et al., 2011; De-Miguel-Molina et al., 2011), although the companies present an individual performance, which meets affected by its pull of resources and capacities (Segarra-Oña \& De-Miguel-Molina, 2009). In this line and focusing on the objectives of the research, we raise our hypotheses:

H1: Small size is a barrier to a company's environmental proactivity.

$\mathrm{H} 2$ : The multinational nature of a company facilitates its proactive orientation.

H3: The direct implication of management is vital to facilitate proactive orientation.

\section{Results Analysis}

The sample of studied companies is composed of 14 enterprises all of them belonging to Castellón's tile industry cluster. One of the objectives of this research is to verify the influence of company size and multinational nature of the companies in environmental proactivity. Therefore the sample is mixed, $50 \%$ of the companies are multinational, and the other $50 \%$ are national. They have been gathered in groups as for the size in small (less than 50 employees), medium (between 50 and 250), and large (more than 250 employees). $71 \%$ of the companies of the sample have own environmental management department, and $29 \%$ carry out the tasks distributed between other departments. $71 \%$ of the companies have environmental accreditation already gained or are in process of obtaining it. It is important to emphasize that even two companies have patents related to environmental actions.

\subsection{Facilitators Identification}

All information gathered is classified according to the characteristics of the companies. First following the size of the company, (small, medium and large company), after the characteristic of the company as for its internationalization (international or national), and then management commitment. The way management environmental commitment is calculated is the following. There are several questions in the questionnaire to measure management environmental commitment, after analysis of the interview results, each company's management gathers points. The management is classified as high commitment, if more than $70 \%$ points are achieved and low commitment if less than $70 \%$ points.

In the following table, the environmental behavior of the companies is characterized, grouping them taking into account the classification before mentioned.

The internal company facilitators observed with the analysis of the realized surveys are three. From the size point of view, in general large companies present better environmental behavior. All international companies have better environmental performance and companies with high management commitment as well.

The aggregation of the surveys and the grouping of the companies according to the different facilitators allow us to see the influence of each one in each of the behaviors that characterize the environmental proactivity, that are detailed in the left column. 
Table 1. Facilitator's identification (\%)

\begin{tabular}{|c|c|c|c|c|c|c|c|c|}
\hline & \multicolumn{3}{|c|}{$\begin{array}{l}\text { Company size } \\
\text { facilitator }\end{array}$} & \multicolumn{2}{|c|}{$\begin{array}{l}\text { Internationalization } \\
\text { facilitator }\end{array}$} & \multicolumn{2}{|c|}{$\begin{array}{c}\text { Management } \\
\text { involvement } \\
\text { facilitator }\end{array}$} & \multirow{2}{*}{$\begin{array}{c}\text { Environmental. } \\
\text { behavior } \\
\text { TOTAL }\end{array}$} \\
\hline & Small & Medium & Large & International & National & High & Low & \\
\hline Energy saving & 55 & 48 & 92 & 82.86 & 48.57 & 79.2 & 40 & 65.71 \\
\hline $\begin{array}{l}\text { Usage of ecological } \\
\text { products in production }\end{array}$ & 55 & 40 & 56 & 65.71 & 34.29 & 53.6 & 45 & 50 \\
\hline Water saving & 60 & 76 & 84 & 91.43 & 57.14 & 84.4 & 55 & 74.29 \\
\hline Waste managed & 85 & 92 & 100 & 100 & 85.71 & 100 & 85 & 92.86 \\
\hline Recyclable products & 30 & 64 & 80 & 71.43 & 48.57 & 78 & 20 & 60 \\
\hline $\begin{array}{l}\text { Training in } \\
\text { environmental matters }\end{array}$ & 55 & 32 & 72 & 62.86 & 42.86 & 61.2 & 40 & 52.86 \\
\hline $\begin{array}{c}\text { Ecological } \\
\text { information used in } \\
\text { marketing }\end{array}$ & 15 & 68 & 84 & 80 & 37.14 & 76.4 & 30 & 58.57 \\
\hline $\begin{array}{l}\text { Environmental costs } \\
\text { and savings quantified }\end{array}$ & 30 & 52 & 80 & 57.14 & 54.29 & 72 & 25 & 55.71 \\
\hline $\begin{array}{c}\text { Information of } \\
\text { measures taken } \\
\text { externally reported }\end{array}$ & 25 & 32 & 44 & 51.43 & 17.14 & 46.4 & 10 & 34.29 \\
\hline $\begin{array}{c}\text { Information of } \\
\text { measures taken } \\
\text { internally reported }\end{array}$ & 25 & 24 & 56 & 45.71 & 25.71 & 49.6 & 10 & 35.71 \\
\hline
\end{tabular}

\subsection{Identification of Obstacles to Environmental Proactivity}

The main obstacles faced by companies when attempting to adopt a more proactive environmental strategy are; lack of institutional support (65.71\%), short financial support (54.29\%), lack of tools information (51.43\%), lack of technical solutions (37.14\%), and lack of qualified human resources $(33 \%)$.

In the following table, the obstacles to environmental proactivity of companies are characterized, grouping them following the same classification; size, internationalization and management commitment.

Table 2. Obstacles to environmental proactivity (\%)

\begin{tabular}{cccccccccc}
\hline & \multicolumn{4}{c}{ Company size facilitator } & \multicolumn{2}{c}{$\begin{array}{c}\text { Internationalization } \\
\text { facilitator }\end{array}$} & $\begin{array}{c}\text { Management } \\
\text { involvement } \\
\text { facilitator }\end{array}$ & $\begin{array}{c}\text { Obstacles to } \\
\text { proactivity }\end{array}$ \\
& Small & Medium & Large & International & National & High & Low & TOTAL \\
\hline $\begin{array}{c}\text { Short financial support } \\
\text { Lack of institutional } \\
\text { support }\end{array}$ & 65 & 64 & 36 & 45.71 & 62.86 & 41.6 & 75 & 54.29 \\
$\begin{array}{c}\text { Lack of tools } \\
\text { information }\end{array}$ & 50 & 72 & 32 & 60 & 42.86 & 49.2 & 55 & 51.43 \\
$\begin{array}{c}\text { Lack of qualified } \\
\text { human resources }\end{array}$ & 25 & 44 & 28 & 45.71 & 20 & 30.8 & 35 & 32.86 \\
$\begin{array}{c}\text { Lack of technical } \\
\text { solutions }\end{array}$ & 15 & 52 & 40 & 57.14 & 17.14 & 46 & 10 & 37.14 \\
\hline
\end{tabular}


Again the aggregation of the surveys and the grouping of the companies according to the different groups allow us to see the influence of each one and the relation with each of the obstacles observed in the left column. This detailed info gives a deep and close overview of each group's needs.

\subsection{Identification of Benefits of Environmental Proactivity}

The companies identify significant benefits arising from the implementation of proactive environmental management actions; the most important one is to avoid sanctions (71.43\%), followed by improvement of the corporate image $(68.57 \%)$. Table 3 shows environmental proactivity benefits detected by the tile industry companies.

Table 3. Benefits of environmental proactivity (\%)

\begin{tabular}{ccccccccc}
\hline & \multicolumn{2}{c}{$\begin{array}{c}\text { Company size } \\
\text { facilitator }\end{array}$} & \multicolumn{2}{c}{$\begin{array}{c}\text { Internationalization } \\
\text { facilitator }\end{array}$} & $\begin{array}{c}\text { Management } \\
\text { involvement } \\
\text { facilitator }\end{array}$ & $\begin{array}{c}\text { Environmental } \\
\text { proactivity } \\
\text { benefits }\end{array}$ \\
& Small & Medium & Large & International & National & High & Low & TOTAL \\
\hline Long-term economic benefits & 35 & 64 & 60 & 71.43 & 37.14 & 62 & 30 & 54.29 \\
Long-term cost savings & 35 & 72 & 68 & 68.57 & 51.43 & 70.8 & 30 & 60 \\
Improvement of corporate & 40 & 68 & 92 & 88.57 & 48.57 & 83.2 & 30 & 68.57 \\
image & & & & & & & \\
New business opportunities & 60 & 48 & 72 & 68.57 & 51.43 & 67.2 & 40 & 60 \\
Increase of customers & 25 & 52 & 52 & 51.43 & 37.14 & 55.2 & 10 & 44.29 \\
Competitiveness increase & 25 & 52 & 52 & 51.43 & 37.14 & 51.2 & 20 & 44.29 \\
Short-term economic benefits & 40 & 44 & 36 & 54.29 & 25.71 & 41.6 & 35 & 40 \\
Short-term cost savings & 35 & 44 & 64 & 71.43 & 25.71 & 58.4 & 30 & 48.57 \\
Avoid sanctions & 55 & 84 & 72 & 74.29 & 68.57 & 77.2 & 55 & 71.43 \\
\hline
\end{tabular}

The aggregation of the surveys and the grouping of the companies according to the different groups allow us to see the influence of each one and the relation with each of the benefits observed in the left column.

\section{Conclusions and Discussion}

\subsection{Modelling Results and Hypotheses Testing}

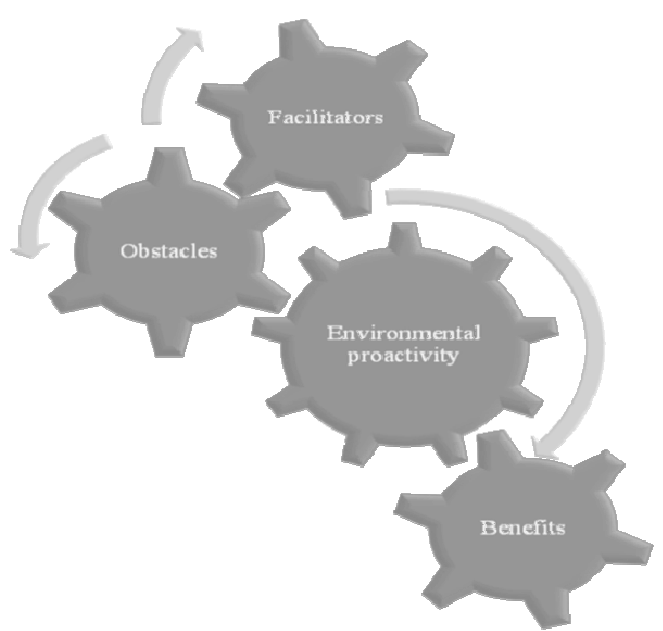

Figure 1. Proactive performance of the tile industry sector

Source: Compiled by authors. 
Environmental proactivity of the tile industry cluster located in Castellón region was studied. The three objectives of this research, facilitators, obstacles faced by companies and benefits of environmental proactivity have been identified. Graphically in Figure 1, the three objectives could be represented by these gears, which may explain companies' environmental proactive behavior.

Hypotheses testing

H1: Small size is a barrier to a company's environmental proactivity.

With the observation of the information obtained with the analysis of the surveys, this hypothesis is not verified. In Table 1, several factors are observed to identify and characterize environmental behavior. They show that there are small companies with a better environmental behavior than medium companies, and even comparable to the behavior of big companies. Evidently, the study is based on the companies of Castellón's tile industry cluster; due to this fact we can conclude that for these companies the size is not a barrier. What happens with our study is that the big size of a company is verified as a facilitator of environmental proactivity.

$\mathrm{H} 2$ : The multinational nature of a company facilitates its proactive orientation.

This hypothesis is fulfilled because all multinational companies (Small, medium or large) have a better environmental behavior than national ones.

H3: The direct implication of management is vital to facilitate proactive orientation.

This hypothesis is fulfilled because all companies with high involvement of management have a better environmental behavior than the other ones.

\subsection{Conclusions}

The major obstacle observed for environmental proactivity is the lack of institutional support (66\%), followed by lack of financial support (54\%), and of lack of information of the tools (51\%). According to the observed company group, there are differences as for the perception of obstacles. The lack of institutional support is the major problem for small companies (75\%), international companies (89\%) and companies with poorly implicated management $(70 \%)$. The shortage of financial support is the major problem for the domestic enterprises (63\%) and for companies with poorly implicated management. The lack of information of the tools is the major problem for the medium companies.

The most important benefit observed from environmental proactivity is to avoid sanctions (71\%), followed by improving the corporate image (68\%), the saving of long-term costs $(60 \%)$ and obtaining new opportunities of business $(60 \%)$. According to the group of companies, there are differences in the perception of benefits of the environmental proactivity. To avoid sanctions is the major benefit waited for medium, national companies and with poorly implicated management. To improve the corporate image is the best benefit for big, international companies and with high implication of management. Whereas the major benefit for small companies is the possibility of obtaining new business opportunities.

To sum up, and according to the results obtained with the analyzed information, we can conclude that in Castellón's tile industry sector, many companies can be found that would be considered to be proactive, and even some as leaders. There are several indicators that show that environmental proactivity is a value taken into account in the strategic planning of companies.

Nevertheless still possibilities of improvement are seen in the fields of institutional support and financial support basically. In the current circumstances of economic crisis, and seen the possible benefits that environmental proactivity can bring, its impulse might contribute with distinguishing factors to help companies exit of the crisis.

Conclusions of this study are not the same as the obtained in similar studies to different industrial sectors in the same region (Segarra-Oña et al., 2011b). What demonstrates that industrial sector is a fact to take into account to understand environmental proactivity (González-Benito \& González-Benito, 2006). The results confirm the importance of management commitment as considered in previous studies as well (González-Benito \& González-Benito, 2010).

Main limitations of this paper are regarding the nature of case studies, conclusions obtained cannot be generalized easily. They may remain in the scope of this study.

\section{Acknowledgement}

The authors would like to thank the Spanish Economy and Competitiveness Ministry for its financial support through the research project (EC02011-27369). Also the Technical University of Valencia for its research 
funding to the project "Innovative impact on the companies' environmental performance: identifying moderating factors" (PAID-06-2011-1879) and for supporting the sabbatical research 2011-2012 course of M. Segarra.

\section{References}

Albors-Garrigós, J., Márquez-Rodríguez, P., \& Hervás-Oliver, J. L. (2008). Las relaciones fabricante distribuidor como elementos básicos de un modelo competitivo en el caso del cluster cerámico español. Análisis empírico de los factores moderadores. Boletín de la Sociedad Española de Cerámicay Vidrio, 47(6), 339-344.

Altomonte, S. (2008). Climate Change and Architecture: Mitigation and Adaptation Strategies for a Sustainable Development. Journal of Sustainable Development, 1(1), 97-112.

Aragón-Correa, J. A. (1998). Strategic proactivity and firm approach to the natural environment. Academy of Management Journal, 41(5), 556-567. http://dx.doi.org/10.2307/256942

Aragón-Correa, J. A., \& Sharma, S. (2003). A Contingent Resource-based view of proactive corporate environmental strategy. Academy of Management Review, 28(I), 71-88.

Aragón-Correa, J. A., Hurtado-Torres, N., Sharma, S., \& García-Morales, V. J. (2008). Environmental strategy and performance in small firms: A resource-based perspective. Journal of Environmental Management, $86(1)$.

Ascer. (2010). Evolución exportaciones baldosas cerámicas. Retrieved from http://www.ascer.es/sectorInformes.aspx?lang=es-ES.

Buysse, K., \& Verbeke, A. (2003). Proactive environmental strategies: A stakeholder management perspective. Strategic Management Journal, 24, 453-470. http://dx.doi.org/10.1002/smj.299

Clarkson, P. M., Li, Y., Richardson, G. D., \& Vasvari, F. P. (2011). Does it really pay to be green? Determinants and consequences of proactive environmental strategies. Journal Account Public Policy, 30, 122-144. http://dx.doi.org/10.1016/j.jaccpubpol.2010.09.013

Crant, M. (2000). Proactive behavior in organizations. Journal of Management, 26(3), 435-462. http://dx.doi.org/10.1177/014920630002600304

Darnall, N., Henriques, I., \& Sadorsky, P. (2008). Do environmental management systems improve business performance in an international setting? Journal of International Management, 14, 364-376. http://dx.doi.org/10.1016/j.intman.2007.09.006

Darnall, N., Henriques, I., \& Sadorsky, P. (2010). Adopting proactive Environmental Strategy: The influence of Stakeholders and Firm size. Journal of Management Studies, 47.

De-Miguel-Molina, B., De-Miguel-Molina, M., \& Albors-Garrigós, J. (2011). The Innovative Regional Environment and the Dynamics of its Clusters. European Planning Studies, 19(10), 1713-1733.

Delmas, M., Hoffmann, V. H., \& Kuss, M. (2011). Under the tip of the Iceberg: Absorptive Capacity, Environmental Strategy, and competitive Advantages. Business and Society, 50(I), 116-154. http://dx.doi.org/10.1177/0007650310394400

Dias-Sardinha, I., \& Reijnders, L. (2005). Evaluating Environmental and social Performance of Large Portuguese companies A Balanced Scorecard approach. Business Strategy and the Environment, 14, 73-91. http://dx.doi.org/10.1002/bse.421

Dubé, L., \& Paré, G. (2003). Rigor in information systems positivist case research: current practices, trends, and recommendations. Mis Quarterly, 27(4), 597-635.

Fairchild, R. (2008). The Manufacturing Sector's Environmental Motives: A Game-theoretic Analysis. Journal of Business Ethics, 79(3), 333-344.

Flyvbjerg, B. (2006). Five Misunderstandings about Case-Study Research. Qualitative Inquiry, 12(2), 219-245.

Gadenne, D. L., Kennedy, J., \& Mckeiver, C. (2009). An empirical Study of environmental Awareness and Practices in SMEs. Journal of Business Ethics, 84, 45-63. http://dx.doi.org/10.1007/s10551-008-9672-9

González-Benito, J., \& González- Benito, O. (2005). Environmental proactivity and business performance: an empirical analysis. Omega Internacional. Journal of Management Science, 33(1), 1-15.

González-Benito, J. \& González-Benito, O. (2006). A review of determinant factors of environmental proactivity. Business Strategy and the Environment, 15, 87-102. 
González-Benito, J., \& González-Benito, O. (2010). A Study of Determinant Factors of Stake Environmental pressure perceived by industrial companies. Business Strategy and the Environment, 19, 164-181

Haddock-Fraser, J. E., \& Tourelle, M. (2010). Corporate Motivations for Environmental Sustainable Development: Exploring the role of consumers in stakeholder engagement. Business Strategy and the Environment, 19, 527-542. http://dx.doi.org/10.1002/bse.663

Kaplan, R. S. (1986). The role for empirical research in management accounting. Accounting, Organizations and Society, 11, 429-452. http://dx.doi.org/10.1016/0361-3682(86)90012-7

King, N. (1994). The qualitative research interview. In Cassel, C., \& y Simon G. (Eds), Qualitative methods in organizational research (pp. 14-36). Ltd. London: Sage Publications.

King, A. A., \& Lenox, M. J. (2001). Does It Really Pay to Be Green? An Empirical Study of Firm Environmental and Financial Performance. Journal of Industrial Ecology, 5(1), 105-116

Lopez-Gamero, M. D., Claver-Cortes, E., \& Molina-Azorin, J. F. (2012). Environmental perception, management, and competitive opportunity in Spanish hotels. Cornell Hospitality Quarterly, 52(4), 480-500.

Martín-Tapia, I., Aragón-Correa, J., \& Rueda-Manzanares, A. (2010). Environmental Strategy and exports in medium, small and micro-enterprises. Journal of World Business, 45, 266-275. http://dx.doi.org/10.1016/j.jwb.2009.09.009

Melnyk, S. A., Sroufe, R. P., \& Calantone, R. (2003). Assessing the impact of environmental management systems on corporate and environmental performance. Journal of Operations Management, 21(3), 329-351.

Miret-Pastor, L., Segarra-Oña, M., \& Peiró-Signes, A. (2011). Identification of service sectors and high technology in Valencia: a new cluster mapping? (In Spanish: Identificación de sectores de servicios y de alta tecnología en la Comunidad Valenciana: Un nuevo cluster mapping?). Revista de estudios regionales, 90, 71-96.

Murillo-Luna, J., Garcés-Ayerbe, C., \& Rivera-Torres, P. (2008). Why do patterns of environmental response differ? A stakeholders' pressure approach. Strategic Management Journal, 29, 1225-1240. http://dx.doi.org/10.1002/smj.711

Piñeiro-García, P., Quintás-Corredoira, M. A., \& Caballero-Fernández, G. (2009). Incidencia de la proactividad medioambiental en el rendimiento de las empresas constructoras españolas. Revista Europea de Dirección y Economía de la Empresa, 18(2), 79-106.

Porter, M. E., \& Van der Linde, C. (1995). Toward a new conception of the environment competitiveness relationship. Journal of Economic Perspectives, 9(4), 97-118.

Rondinelli, D., \& Vastag, G. (2000). Panacea, common sense or just a label? The value of ISO 14001 Environmental management systems. European Management Journal, 18(5), 499-510. http://dx.doi.org/10.1016/S0263-2373(00)00039-6

Rouse, M. J., \& Daellenbach, U. S. (1999). Rethinking research methods for the resource-based perspective: isolating sources of sustainable competitive advantage. Strategic Management Journal, 20, 487-494.

Segarra-Oña, M., \& De-Miguel-Molina, B. (2009). Evaluación de la Concentración Industrial Sinérgica: propuesta metodológica y aplicación a un sector industrial. TEC Empresarial 65, 3(1-2), 65-72.

Segarra-Oña, M., Carrascosa-López, C., Segura-García-del-Río, B., \& Peiró-Signes, A. (2011a). Empirical analysis of the integration of environmental proactivity into managerial strategy. Identification of benefits, difficulties and facilitators at the Spanish automotive industry. Environmental Engineering and Management Journal, 10(12), 1821-1830.

Segarra-Oña, M., Peiró-Signes, A., Miret-Pastor, L., \& Verma, R. (2011b). Eco-innovation attitude and industry's tecnological level. An important key for promoting efficient vertical policies. Environmental Engineering and Management Journal, 10(12), 1893-1901.

Sharfman, M. P., \& Fernando, C. S. (2008). Environmental risk management and the cost of capital. Strategic Management Journal, 29, 569-592. http://dx.doi.org/10.1002/smj.678

Stake, R. E. (1995). The art of case study research. Thousand Oaks, CA. Sage.

Tortajada, E., Gabaldón, D. J., \& Fernández, I. (2008). La evolución tecnológica del distrito cerámico de castellón: la contribución de la industria de fritas, colores y esmaltes. Boletín de la Sociedad Española de Cerámica y Vidrio, 47(2), 57-80. 
Vargas-Vargas, M., Meseguer-Santamaría, M. L., Mondéjar-Jiménez, J., \& Mondéjar-Jiménez, J. A. (2010) Environmental Protection Expenditure for Companies: A Spanish Regional Analysis. International Journal of Environmental Research, 4(3), 373-378. 